\title{
Mitigasi Sebaran Narkoba Melalui Sistem Informasi Geografis di Kota Pekalongan dengan Integrasi Global Mapper dan Google Earth
}

\author{
Tri Agus Setiawan ${ }^{1}$, Hermanus Wim Hapsoro ${ }^{2}$, Agus Ilyas $^{3}$ \\ ${ }^{1,2}$ Teknik Informatika - STMIK Widya Pratama Pekalongan \\ ${ }^{3}$ Manajemen Informatika - STMIK Widya Pratama Pekalongan \\ e-mail: ${ }^{1}$ tri.triagus.setiawan45@gmail.com, ${ }^{2}$ wimhapsoro06@ gmail.com, \\ 3ilyasagus@gmail.com
}

\begin{abstract}
Abstrak
Sebaran dan tindak kejahatan narkoba di Wilayah Polres Kota Pekalongan sudah memprihatinkan dan sudah merambah berbagai profesi dan lintas generasi. Adapun sistem monitoring untuk pemetaannya masih menggunakan peta statis. Adapun masalah dalam penelitian yaitu belum adanya sistem informasi geografis pemetaan daerah rawan dan sebaran kasus narkoba berbasis web. Penelitian dilakukan dengan metode Research and Development, untuk mitigasi area sebaran narkoba menggunakan tools Global Mapper adapun Google Earth untuk melakukan proses geospasial. Dari hasil penelitian yang dilakukan dapat menghasilkan Aplikasi SIG Sebaran Narkoba yang mampu menampilkan daerah rawan dan sebaran kasus narkoba berdasarkan wilayah dan tahun kejadian serta fasailitas edukasi sehingga dapat menjadi referensi dan bahan kajian baik Polres Pekalongan Kota maupun Pemerintah kota Pekalongan tentang Narkoba.
\end{abstract}

Kata Kunci: Google Earth, SIG, Global Mapper, Narkoba

\begin{abstract}
The distribution and acts of drug crimes in the Pekalongan City Police Area have been a concern and have penetrated various professions and across generations. The monitoring system for mapping still uses a static map. The problem in this research is the absence of a geographic information system for mapping vulnerable areas and the distribution of web-based drug cases. The research was conducted using the Research and Development method, to mitigate the area of drug distribution using the Global Mapper tools, while Google Earth to carry out the geospatial process. From the results of the research carried out, it can produce a GIS Application for the Distribution of Drugs that is able to display the vulnerable areas and distribution of drug cases by region and year of occurrence as well as educational facilities so that they can be a reference and study material for both the Pekalongan City Police and the Pekalongan City Government on Drugs.
\end{abstract}

Keywords: Drugs, GIS, Global Mapper, Google Earth

\section{Pendahuluan}

Kota Pekalogan adalah daerah rawan Narkoba dan termasuk 10 besar dalam penyalahgunaan narkoba untuk wilayah jawa tengah. Penyalahgunaan narkoba sangat berbahaya karena efek yang ditimbulkan menyebabkan ketergantungan, halusinasi dan beragam penyakit serta mempengaruhi Psikologi dan fisik [1], [2], [5]. Kejahatan narkoba biasanya terorganisir dengan baik dan para pelaku dan bandar biasanya tidak saling mengenal atau terputus sehingga bandar lolos dari jerat hukum [3]. Untuk memberikan data penyalahgunaan narkoba masih terdapat kendala yaitu belum ada website yang memberikan data informasi tentang pemetaan/mitigasi daerah rawan narkoba, sebaran kasus dan edukasi secara onlie dalam satu sistem.

Studi literatur mengambil beberapa referensi yang memiliki kesesuian tema yaitu Kaseger [1]hasil penelitiannya berupa deteksi dan mitigasi daerah rawan narkoba, Andrianto [2] 
mengasilkan SIG mitigasi titik kerawanan kasus narkoba di wilayah Poresta Solok. Dari hasil penelitian yang dilakukan dihasilkan gap penelitian sebelumnya terhadap fitur dan software yang digunakan, pada penelitian yang dilakukan Kaseger [1] software yang digunakan dengan PHP, CSS dan belum ada data kasus kriminalitas dari tahun sebelumnya, pada penelitian Andrianto [2] menggunakan PHP dan belum ada pengelompokan/klasterisasi kasus narkoba berdasarkan desa/kelurahan, kedua penelitian yang dilakukan untuk menggambarkan peta hanya menggunakan google maps sehingga dalam menentukan daerah rawan narkoba berdasarkan tingkat kerawanan belum dapat dilakukan.

Berdasarkan analisa yang dilakukan terhadap referensi dari studi literatur yang ada maka penelitian yang dilakukan memiliki kelebihan ataupun perbaikan yaitu penggunakan framework Codeigniter, CSS, Bootstrap dalam membuat web GIS sehingga tampilan lebih menarik dan responsive, adapaun dalam membuat pemetaan peneliti menggunakan Global Mapper untuk mengelola data attribute berupa kecamatan, kelurahan, jenis narkoba dan tahun kejadian, kemudian mengelola dan convert data vektor dan raster peta menjadi file bertipe KML. Adapaun Google Earth digunakan untuk tampilan geospasial berbasis cloud berdsarkan data yang dioleh di Global Mapper. Dari sini data diolah kembali dengan memberikan warna sehingga ada pembeda antara lokasi satu dengan lainnya. sebaran kasus narkoba sekaligus dapat digunakan sebagai referensi dan bahan kajian baik Polres Pekalongan Kota maupun Pemerintah kota Pekalongan tentang Narkoba.

Penerapan metode Penelitian dan Pengembangan (R\&D) [6] untuk mendapatkan data dan informasi berkaitan mitigasi daerah terjadinya kasus, sebaran, jumlah kasus dan tahun kejadian yang diperoleh dari Serse Polresta Pekalongan dan BNN. Penggunaan mitigasi SIG [3] dengan melakukan integrasi Global Mapper [8] untuk mendapatkan kawasan persebaran narkoba dengan tipe normal (hijau), sedang (kuning) rawan (merah) [4] dan Google Earth menghasilkan output dalam bentuk peta spasial [9], [5], [11], [6], [7], website SIGAP dari hasil penelitian juga memiliki fitur pembelajaran sebagai upaya preventif dalam mengurangi dampak narkoba [12], [8]. Selain itu juga memudahkan dalam proses mitigasi dan monitoring [13], [14], [15], [9] menurut tingkat kerawanan, sebaran dan jenis narkoba serta terjadinya kasus.

Berdasarkan permasalahan dan studi literatur yang ada maka solusi sebagai hasil penelitian yang dilakukan dengan mengintegrasikan Global Mapper dan Google Earth adalah sistem mitigasi berupa Sistem Informasi Geografis Sebaran Kasus Narkoba (SIGAP) di wilayah hukum Polres Pekalongan Kota dan mampu menampilkan daerah rawan narkoba, sebaran kasus, tahun kejadian dan fasailitas edukasi sehingga diharapkan mampu mengurangi jumlah kasus narkoba dan bahan kajian untuk Polres Pekalongan kota maupun pemerintah kota Pekalongan.

\section{Metode Penelitian}

Metode yang dilakukan pada penelitian ini dengan metode Penelitian dan Pengembangan $(R \& D)$ [10] dimana hasil akhir penelitian bukan melakukan pengujian terhadap teori akan tetapi membuat aplikasi yaitu website SIGAP. Untuk metode penelitiannya sesuai Gambar 2:

\subsection{Metode Pengumpulan Data}

Proses pegumpulan data melalui tahapan:

a. Pengamatan, pengamatan dilakukan di wilayah hukum Polres Pekalongan Kota dengan mengumpulkan data dan informasi tentang mitigasi kasus narkoba, sebaran dan waktu kejadian berlangsung.

b. Wawancara, wawancara dilakukan secaara langsung terhadap Serse Narkoba dan BNN

c. Sampling, untuk menggambarkan mitigasi sebaran kasus narkoba tidak semua ditampilkan akan tetapi beberapa wilayah saja sebagi contoh wilayah kecamatan Pekalongan Timur, kelurahan Sokorejo, jenis narkoba Sabu-sabu dan tahun kejadian 2019 maka akan muncul wilayah dan tingkat kerawanannya.

\subsection{Tahapan Penelitian}

Penelitian dalam membuat website SIGAP dilaksanakan dengan tahapan: 
a. Survey dan Pengumpulan Data.

Survey dilakukan dengan melakukan kunjungan di kantor Serse Narkoba Polres Pekalongan

Kota dan kantor BNN, Adapun dari proses pengumpulan data diperoleh data dan informasi tentang daerah sebaran narkoba dan tingkat kerawanannya, kasus narkoba berdasarkan jenis dan jumlah kasus serta tahun kejadian, dokumen dan materi tentang edukasi narkoba serta data spasial dan atribut wilayah dalam bentuk koordinat Latitude-Longitude melalui laman https://tanahair.indonesia.go.id/

b. Pengolahan Data

Tahapan yang dilakukaan sebagai berikut:

1) Data berupa sebaran dan jumlah kasus, jenis narkoba, artikel, gambar, video, dokumen diolah dalam bentuk tabel dan disimpan dalam database sigap_sig.sql menggunakan Xampp dan MySql.

2) Data peta Kota Pekalongan yang diperoleh dari https://tanahair.indonesia.go.id/ kemudian dijadikan dasar untuk menggambarkan daerah sebaran dan tingkat kerawanan kasus narkoba dengan menggunakan Google Mapper sehingga diperoleh data dalam bentuk KML, setelah itu untuk menampilkan hasil dan memvisualisasikan gambar geospasialnya menggunakan Google Earth sehingga dapat digunakan secara online.

3) Untuk kegiatan coding dalam membuat website menggunakan framework Codeigniter, bootstrap, CSS agar tampilan menarik dan responsive

c. Pengujian

Kegiatan pengujian terhadap user interface, lembar kerja tampilan, fungsi tombol apakah dapat digunakan dan berjalan dengan benar [11], selain itu pengujan dilakukan untuk mengetahui kesalahan yang ada pada saat perancangan, modeling dan coding.

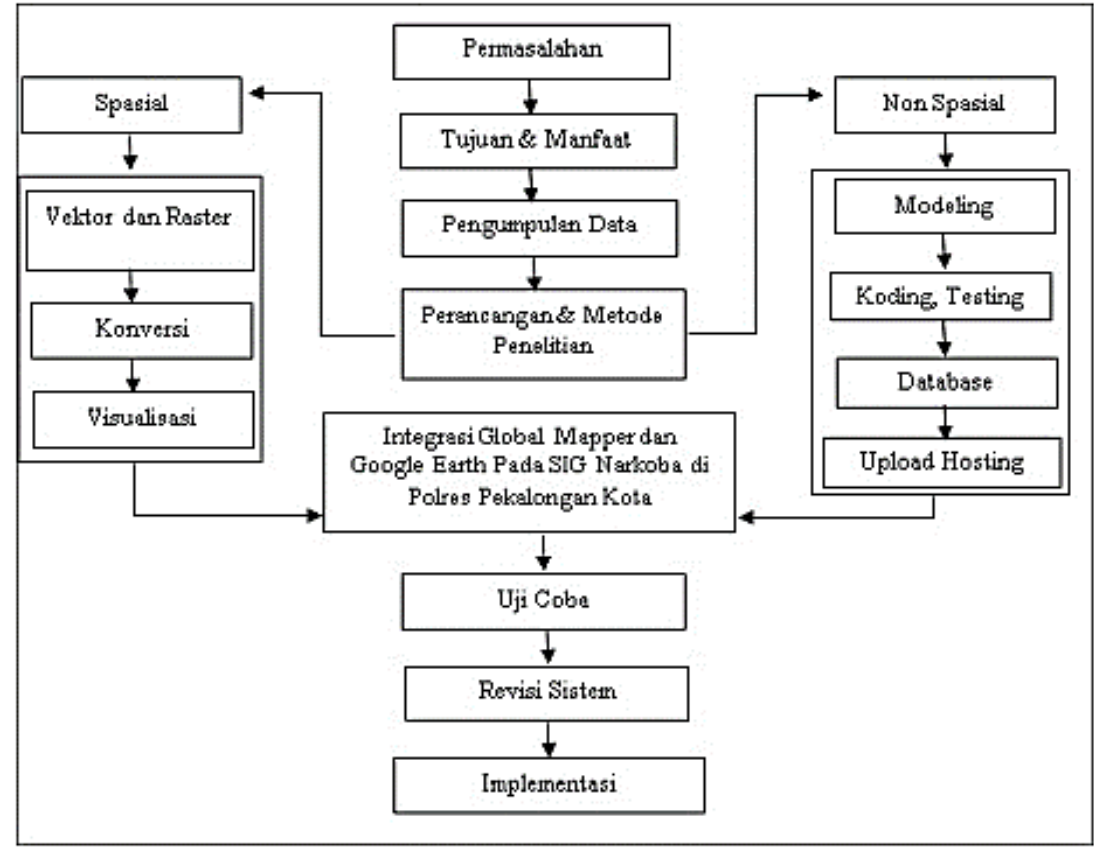

Gambar 1 Metodologi Penelitian

\subsection{Perancangan Model}

Proses modeling dalam pembuatan website SIGAP menggunakan Unified Modeling Language (UML)[12] dengan tahapan:

1) Use Case Diagram

Menerangkan interaksi user terhadap sistem (use case dan actor) yang dibangun dengan kelengkapan fitur beranda, edukasi, sebaran narkoba, download dan kontak sesuai pada Gambar 2. 


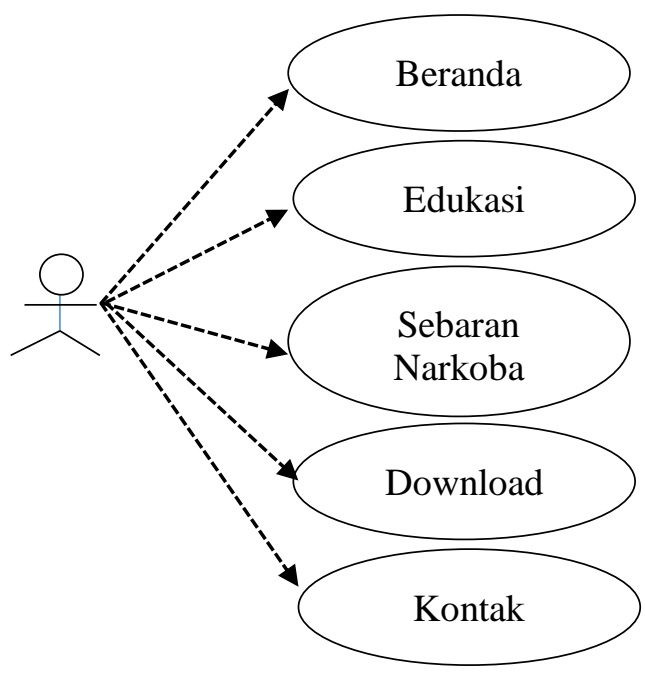

\section{Gambar 2 Use Case Diagram}

2) Diagram Aktifitas

Menjelaskan mekanisme aktifitas dari sistem yang berjalan, pada sebaran narkoba user akan menjalankan kegiatan filtering berdasarkan kecamatan, kelurahan, jenis narkoba, tahun sesuai kebutuhan kemudian hasilnya akan ditampilkan dalam bentuk peta sebaran wilayah kasus narkoba termasuk data detail informasi kasus yang ada. Adapaun diagram aktifitas seperti pada Gambar 3:

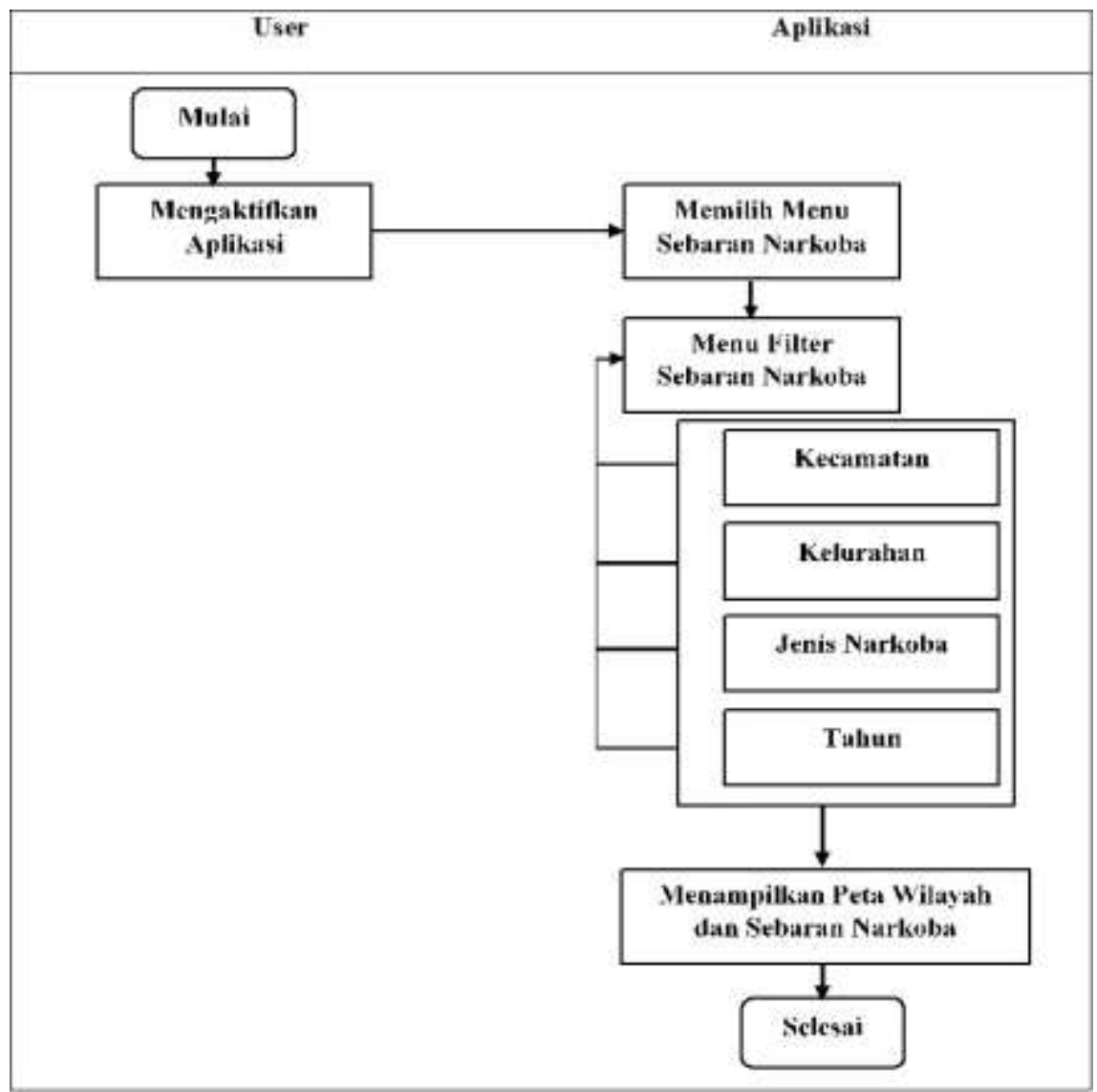

Gambar 3 Diagram Aktifitas 


\section{Hasil dan Pembahasan}

Sesuai hasil interview dari Serse Narkoba dan BNN bahwa belum ada website yang memberikan data informasi tentang pemetaan daerah rawan narkoba, sebaran kasus dan edukasi secara onlie dalam satu sistem, kemudia dilakukan literarur review yang merujuk referensi penelitian yang memiliki topik tentang sistem informasi geografis narkoba dimana pada penelitian sebelumnya memiliki kelemahan yaitu belum mampu menampilkan area/daerah rawan sebaran narkoba, belum ada fasilitas untuk menambah data kasus kriminalitas dari tahun sebelumnya, belum ada klasterisaasi berdasarkan desa/kelurahan, belum mampu menampilkan daerah-daerah rawan narkoba berdasarkan tingkat kerawanan.

\subsection{Data Sebaran Narkoba}

Dari hasil interview yang dilakukan di Serse Narkoba berkenaan jumlah kasus dan sebarannya didapatkan data pada Tabel 1 .

\section{Tabel 1 Data Sebaran Narkoba Berdasarkan Jenisnya}

\begin{tabular}{cll}
\multicolumn{3}{c}{ Kecamatan Pekalongan Utara } \\
\hline No & Kelurahan & \multicolumn{1}{c}{ Jenis Narkoba } \\
\hline 1 & Bandengan & Ganja \\
2 & Degayu & Alphrazolam, Dextro \\
& & \\
3 & Krapyak & Ganja, Alphrazolam, \\
& & Dextro \\
4 & Kandang & Sabu-sabu, \\
& Panjang & Alphrazolam, Dextro \\
5 & Panjang & Sabu-sabu, Ganja \\
& Baru & \\
6 & Panjang & Sabu-sabu, Ganja, \\
& Wetan & Alphrazolam, Dextro \\
7 & Padukuhan & Sabu-sabu, \\
& Kraton & Alphrazolam, Dextro \\
\hline
\end{tabular}

\begin{tabular}{|c|c|c|}
\hline \multicolumn{3}{|c|}{ Kecamatan Pekalongan Timur } \\
\hline No & Kelurahan & Jenis Narkoba \\
\hline 1 & Noyontaansari & \\
\hline 2 & Kauman & $\begin{array}{l}\text { Sabu-sabu, } \\
\text { Alphrazolam, Dextro }\end{array}$ \\
\hline 3 & Poncol & $\begin{array}{l}\text { Sabu-sabu, Ganja, } \\
\text { Alphrazolam, Dextro }\end{array}$ \\
\hline 4 & Klego & Sabu-sabu \\
\hline 5 & Gamer & $\begin{array}{l}\text { Sabu-sabu, Ganja, } \\
\text { Alphrazolam, Dextro }\end{array}$ \\
\hline 6 & Setono & Sabu-sabu \\
\hline 7 & Kalibaros & Sabu-sabu \\
\hline
\end{tabular}

Kecamatan Pekalongan Barat

Kecamatan Pekalongan Selatan

\begin{tabular}{|c|c|c|}
\hline No & Kelurahan & Jenis Narkoba \\
\hline 1 & Bendan & Sabu-sabu, \\
\hline & Kergon & Alphrazolam, Dextro \\
\hline 2 & Medono & Sabu-sabu, Ganja \\
\hline 3 & $\begin{array}{l}\text { Pasirkraton } \\
\text { kramat }\end{array}$ & $\begin{array}{l}\text { Sabu-sabu, Ganja, } \\
\text { Alphrazolam, Dextro }\end{array}$ \\
\hline 4 & Podosugih & $\begin{array}{l}\text { Sabu-sabu, Ganja, } \\
\text { Alphrazolam, Dextro }\end{array}$ \\
\hline 5 & Pringrejo & $\begin{array}{l}\text { Sabu-sabu, Ganja, } \\
\text { Alphrazolam, Dextro }\end{array}$ \\
\hline 6 & $\begin{array}{l}\text { Sapuro } \\
\text { Kebulen }\end{array}$ & Alphrazolam, Dextro \\
\hline 7 & Tirto & Sabu-sabu \\
\hline
\end{tabular}

\begin{tabular}{cll}
\hline No & Kelurahan & \multicolumn{1}{c}{ Jenis Narkoba } \\
\hline 1 & Banyurip & $\begin{array}{l}\text { Sabu-sabu, Ganja, } \\
\text { Alphrazolam, Dextro }\end{array}$ \\
2 & Buaran & Sabu-sabu, \\
& Kradenan & Alphrazolam, Dextro \\
3 & Jenggot & $\begin{array}{l}\text { Ganja, Alphrazolam, } \\
\text { Dextro }\end{array}$ \\
4 & Kuripan & Sabu-sabu \\
& $\begin{array}{l}\text { Kertoharjo } \\
5\end{array}$ & Kuripan \\
& Yosorejo & Sabu-sabu \\
6 & Sokoduwet & \\
& & \\
\hline
\end{tabular}

Tingkat kerawanan kasus narkoba yang terjadi di tahun 2020 periode September pada Tabel 2: 
Tabel 2 Mitigasi Sebaran Kasus Narkoba

\begin{tabular}{|c|c|c|c|c|c|}
\hline \multicolumn{6}{|c|}{ Pekalongan Utara } \\
\hline \multirow[t]{2}{*}{ No } & \multirow[t]{2}{*}{ Kelurahan } & \multicolumn{3}{|c|}{ Jumlah Kasus } & \multirow[t]{2}{*}{ Jumlah } \\
\hline & & Sabu-Sabu & Ganja & Alphrazolam/Dextro & \\
\hline 1 & Bandengan & & 2 & & 2 \\
\hline 2 & Degayu & & & 1 & 1 \\
\hline 3 & Krapyak & & 1 & 1 & 2 \\
\hline 4 & Kandang Panjang & 2 & & 2 & 4 \\
\hline 5 & Panjang Baru & 1 & 1 & & 2 \\
\hline 6 & Panjang Wetan & 8 & 2 & 1 & 11 \\
\hline 7 & Padukuhan Kraton & 2 & & 1 & 3 \\
\hline \multicolumn{6}{|c|}{ Pekalongan Timur } \\
\hline \multirow[t]{2}{*}{ No } & \multirow[t]{2}{*}{ Kelurahan } & \multicolumn{3}{|c|}{ Jumlah Kasus } & Jumlah \\
\hline & & Sabu-Sabu & Ganja & Alphrazolam/Dextro & \\
\hline 1 & Noyontaansari & & & & 0 \\
\hline 2 & Kauman & 4 & & 1 & 5 \\
\hline 3 & Poncol & 3 & 2 & 3 & 8 \\
\hline 4 & Klego & 2 & & & 2 \\
\hline 5 & Gamer & 1 & 1 & 1 & 3 \\
\hline 6 & Setono & 5 & & & 5 \\
\hline 7 & Kalibaros & 1 & & & 1 \\
\hline
\end{tabular}

Pekalongan Barat

\begin{tabular}{|c|c|c|c|c|c|}
\hline \multirow{2}{*}{ No } & \multirow{2}{*}{ Kelurahan } & \multicolumn{3}{|c|}{ Jumlah Kasus } & \multirow[b]{2}{*}{ Jumlah } \\
\hline & & Sabu-Sabu & Ganja & Alphrazolam/Dextro & \\
\hline 1 & Bendan Kergon & 2 & & 2 & 4 \\
\hline 2 & Medono & 4 & 3 & & 7 \\
\hline 3 & Pasirkratonkramat & 8 & 3 & 2 & 13 \\
\hline 4 & Podosugih & 3 & 2 & 3 & 8 \\
\hline 5 & Pringrejo & 5 & 1 & 6 & 12 \\
\hline 6 & Sapuro Kebulen & & & 2 & 2 \\
\hline 7 & Tirto & 1 & & & 1 \\
\hline \multicolumn{6}{|c|}{ Pekalongan Selatan } \\
\hline \multirow{2}{*}{ No } & \multirow{2}{*}{ Kelurahan } & \multicolumn{3}{|c|}{ Jumlah Kasus } & \\
\hline & & Sabu-Sabu & Ganja & Alphrazolam/Dextro & Jumlah \\
\hline 1 & Banyurip & 2 & 1 & 2 & 5 \\
\hline 2 & Buaran Kradenan & 3 & & 3 & 6 \\
\hline 3 & Jenggot & & 1 & 8 & 9 \\
\hline 4 & Kuripan Kertoharjo & 2 & & & 2 \\
\hline 5 & Kuripan Yosorejo & 2 & & & 2 \\
\hline 6 & Sokoduwet & & & & 0 \\
\hline
\end{tabular}




\subsection{Letak Kelurahan}

Dalam menentukan posisi kelurahan menurut latitude dan longitude sesuai Tabel 3:

Tabel 3 Letak Kelurahan

\begin{tabular}{cclrr}
\hline Kecamatan & $\begin{array}{c}\text { Kode } \\
\text { Kelurahan }\end{array}$ & \multicolumn{1}{c}{ Kelurahan } & Latitude & Longitude \\
\hline Pekalongan Timur & 5 & Noyontaansari & $-6,912521100$ & 109,67545 \\
& 5 & Kauman & $-6,891052500$ & 109,67372 \\
& 5 & Poncol & $-6,900907400$ & 109,67651 \\
& 5 & Klego & $-6,882379700$ & 109,66584 \\
& 5 & Gamer & $-6,892770400$ & 109,69166 \\
Pekalongan Barat & 5 & Setono & $-6,903233500$ & 109,68867 \\
& 5 & Kalibaros & $-6,906799700$ & 109,68804 \\
& 6 & Bendan Kergon & $-6,894025600$ & 109,66901 \\
& 6 & Medono & $-6,893761100$ & 109,65598 \\
& 6 & Pasirkratonkramat & $-6,887175500$ & 109,64617 \\
Pekalongan Selatan & 6 & Podosugih & $-6,893195100$ & 109,65120 \\
& 6 & Pringrejo & $-6,893761100$ & 109,65598 \\
& 6 & Sapuro Kebulen & $-6,901389800$ & 109,67391 \\
& 6 & Tirto & $-6,907655600$ & 109,64720 \\
& 7 & Banyurip & $-6,916626000$ & 109,64800 \\
& 7 & Buaran Kradenan & $-6,913490000$ & 109,65073 \\
& 7 & Jenggot & $-6,893761100$ & 109,65598 \\
& 7 & Kuripan Kidul Kertoharjo & $-6,928522900$ & 109,66410 \\
& 7 & Kuripan Lor Yosorejo & $-6,912542400$ & 109,67545 \\
& 7 & Sokoduwet & $-6,923591700$ & 109,64489 \\
& 8 & Bandengan & $-6,872571400$ & 109,66196 \\
& 8 & Degayu & $-6,886267000$ & 109,70146 \\
& 8 & Krapyak & $-6,872745100$ & 109,68074 \\
& 8 & Kandang Panjang & $-6,873410100$ & 109,67233 \\
& 8 & Panjang Baru & $-6,868967400$ & 109,67002 \\
& & Panjang Wetan & $-6,868843600$ & 109,66636 \\
& & & $-6,893761100$ & 109,65598 \\
\hline & & &
\end{tabular}

\subsection{Data Spasial}

Untuk membuat aplikasi website SIGAP dilakukan dengan langkah:

1. Database

Untuk menampung semua data dalam website SIG SIGAP disimpan pada database sigap_sig.sql terdiri dari 13 tabel.

2. Sebagai dasar melakukan mitigasi pada pembuatan aplikasi berbasis SIG maka langkah awal yang harus dilakukan dengan mengambil data melalui https://tanahair.indonesia.go.id/ yang memiliki ekstensi SHP.

3. Untuk pengolahan file tersebut maka digunakan Global Mapper [13] untuk membuat mitigasi wilayah kasus narkoba dan penyebarannya. Peta yang didownload dalam keadaan di Compress. Extract File tersebut kemudian pilih file yang berextensi SHP (ShapeFile) seperti pada Gambar 4: 


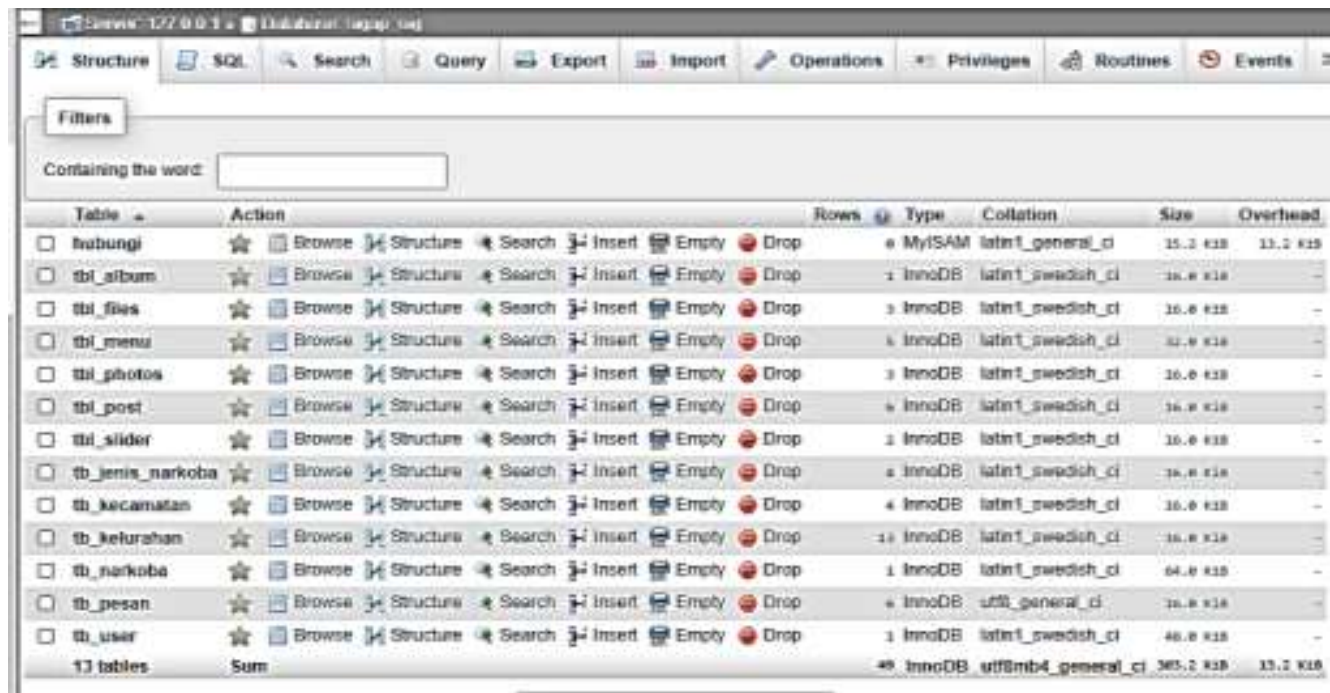

\section{Gambar 4. Database SIG SIGAP}

4. Sebagai dasar melakukan mitigasi pada pembuatan aplikasi berbasis SIG maka langkah awal yang harus dilakukan dengan mengambil data melalui https://tanahair.indonesia.go.id/ yang memiliki ekstensi SHP.

5. Untuk pengolahan file tersebut maka digunakan Global Mapper [13] untuk membuat mitigasi wilayah kasus narkoba dan penyebarannya. Peta yang didownload dalam keadaan di Compress. Extract File tersebut kemudian pilih file yang berextensi SHP (ShapeFile) seperti pada Gambar 5:

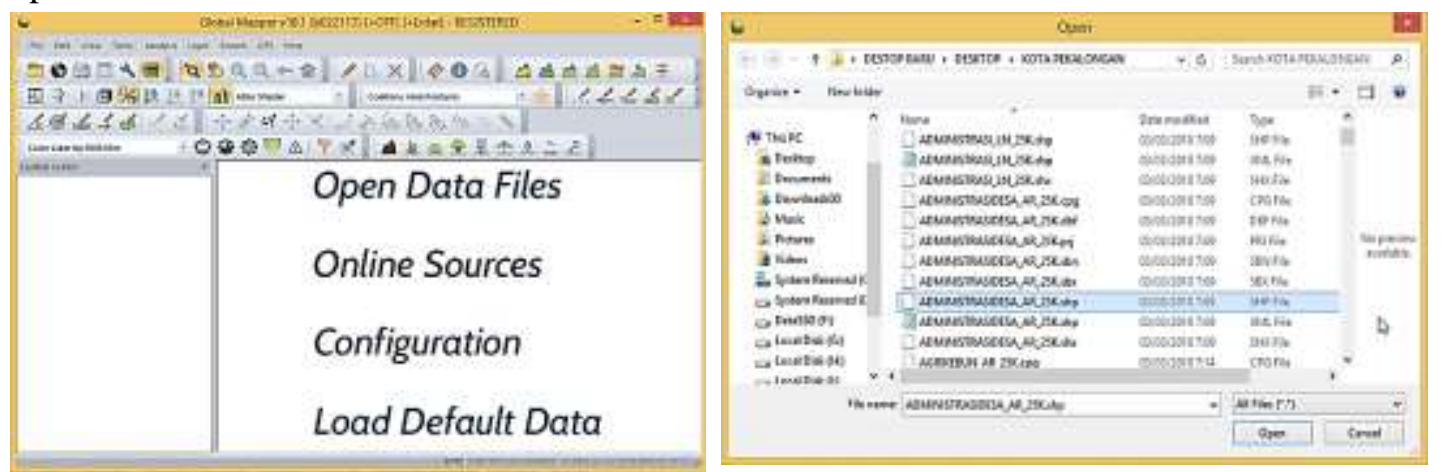

\section{Gambar 5 Hasil Proses Pembuatan Peta Menggunakan Global Mapper}

6. Proses editing dengan menggabungkn atau menghapus peta yang ada kesalahannya sehingga peta siap untuk digunakan

7. Export peta dengan perintah File >>Export $>>$ Export Vector /Lidar Format $>>$ KML / KMZ Klik Ok Pilih KML

8. Hasil Pemprosesan berupa file KML dengan tampilan sebagai berikut Contoh salah satu Kelurahan Jeruk Sari.

9. Panggil Google Earth kemudian import file KML, kegiatan penyatuan file di website menggunakan Google Earth menghasilkan tampilan geospasial [14], [15], [16], [17] berbasis cloud sehingga user atau admin dapat melakukan pemantauan maupun analisis pada sebaran kasus narkoba di wilayah Polres Pekalongan Kota.

10. Berilah Warna dengan Klik Kanan Pilih Properties Pilih Lokasi dan warna yang di inginkan Setelah Selesai di Pada Objek lokasi klik Kanan Pilih Simpan tempat sebagai, Tuliskan Nama file dan exensi pilih KML. 
11. File KML dari Google Earth ini harus disimpan di cloude kemudian di dipanggil lewat program website yang sudah dibuat seperti pada Gambar 6:

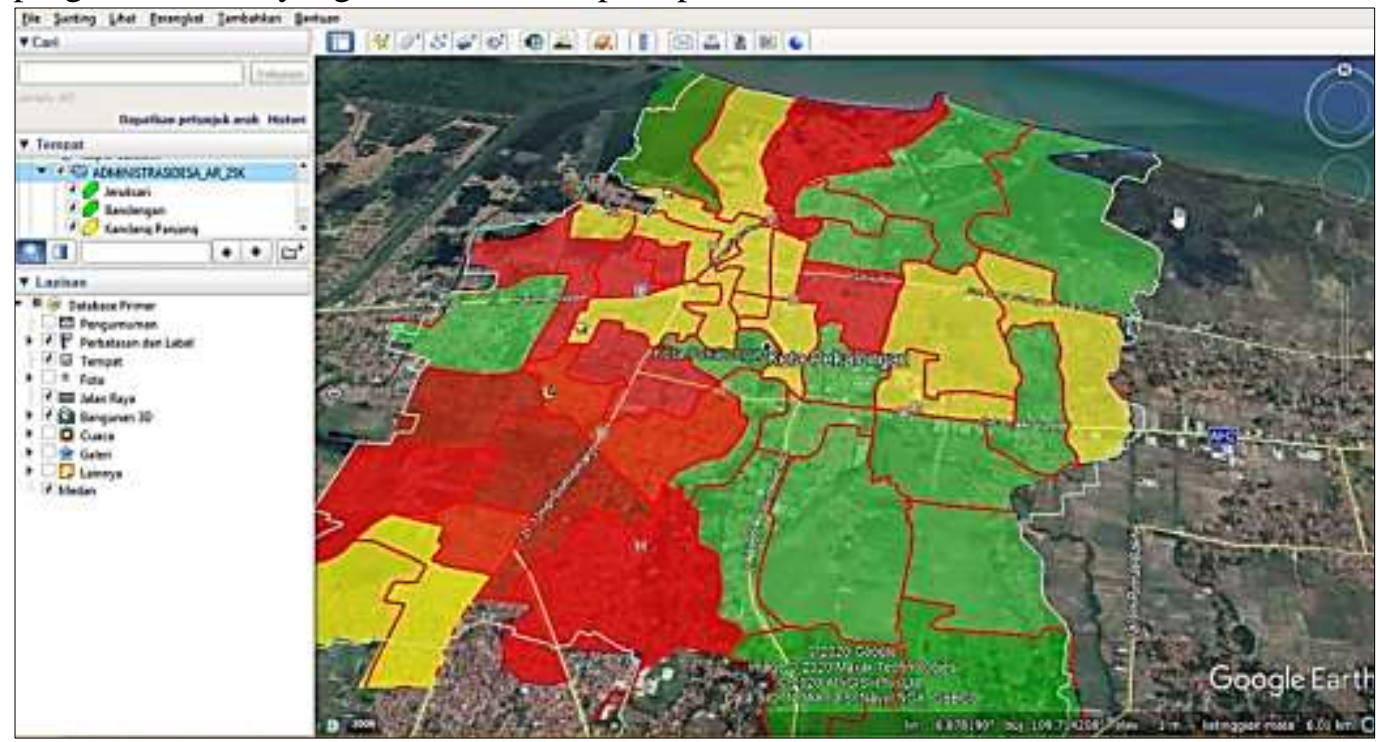

Gambar 6 Hasil Proses Geospasial Menggunakan Google Earth

12. Hasil penggabungan Google Mapper dan Google Earth dengan menghasilkan file dalam bentuk KML, kemudian dilakukan proses coding dengan framework Codeigniter. Untuk proses pengujian maka user dapat melihat daerah rawan dan sebaran kasus narkoba dengan melakukan filtering berdasarkan wilayah kecamatan, kelurahan, jenis narkoba dan tahun terjadinya kasus secara lengkap dan akan menghasilkan output seperti pada Gambar 7:

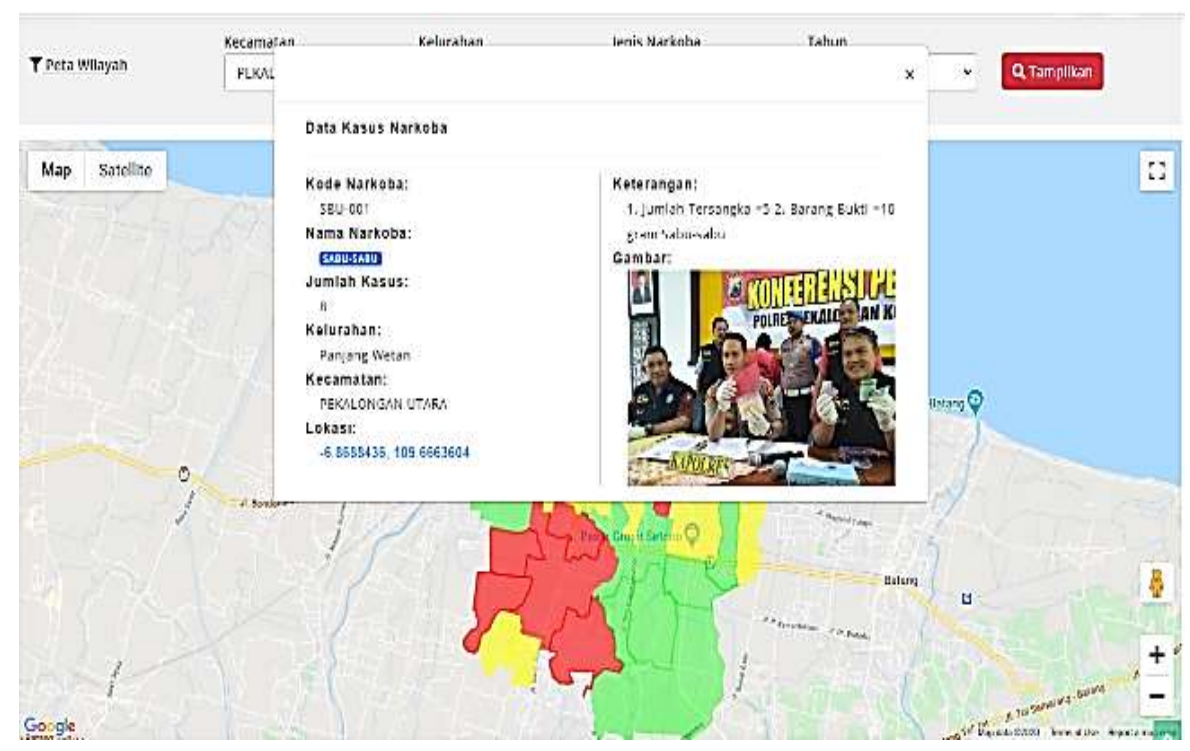

Gambar 7 Hasil Proses Pencarian Informasi Dengan Menu Detail

Fitur pembelajaran belum ada dalam penelitian-penelitian sebelumnya, konsep pembelajaran digunakan untuk penyuluhan [3] terhadap pelajar, mahasiswa maupun masyarakat secara luas mengenai resiko,bahaya dan penanganan narkoba [18], [19]. Pada menu edukasi juga menyediakan data, artikel, dokumen, ataupun peraturan perundang-undangan yang dibutuhkan untuk tindakan preventif dalam rangka menurunkan kriminalitas dan kasus narkoba. 


\section{Kesimpulan}

Berdasarkan penelitian maka disimpulkan untuk Polres Pekalongan Kota belum memiliki SIG tentang sebaran kasus narkoba berbasis web dan juga pada penelitian sebelumnya tidak menampilkan daerah rawan/klasterisasi dan sebaran kasus narkoba. Untuk mengatasi masalah tersebut maka penelitian yang dilakukan menggunakan Global Mapper untuk mengelola data attribute berupa kecamatan, kelurahan, jenis narkoba dan tahun kejadian, kemudian mengelola dan convert data vektor dan raster peta menjadi file bertipe KML. Adapaun Google Earth digunakan untuk tampilan geospasial berbasis cloud berdasarkan data yang diolah di Global Mapper, dengan demikian mitigasi dan monitoring dapat dilaksanakan secara online. Penerapan kedua aplikasi diatas terbentuk aplikasi SIG yang dapat melakukan mitigasi, monitoring dan pembelajaran terhadap kasus narkoba serta sebarannya sekaligus dapat digunakan sebagai referensi dan bahan kajian baik Polres Pekalongan Kota maupun Pemerintah kota Pekalongan tentang Narkoba.

Sebagai tindak lanjut hasil penelitian dapat dilakukan pengembangan dengan menambahkan fitur status dari proses hukum yang ada terhadap pelaku kasus narkoba yang ada pada bagian admin atau pengelola website sehingga diketahui status hukum pada tiap-tiap kasus.

\section{Ucapan Terimakasih}

Terimasih kami ucapkan terhadap Kementerian Riset dan Teknologi Pendidikan Tinggi, Ketua STMIK Widya Pratama, P3M, Ketua Program Studi, Kepolisian Resort Pekalongan Kota, BNN, tim peneliti, dosen serta keluarga sehingga dapat menyelesiakan Hibah Penelitian Dosen Pemula Tahun 2020.

\section{Daftar Pustaka}

[1] M. A. Kaseger et al., "Aplikasi Pemetaan Daerah Rawan Kriminalitas di Manadi Berbasis Web," J. Tek. Inform., vol. 3, no. 2, pp. 439-452, 2018.

[2] Andrianto and M. Jazman, "Sistem Informasi Geografis Pemetaan Titik Lokasi Daerah Rawan Kriminalitas Kota Solok ( Studi Kasus: Polres Solok Kota )," SNTIKI, no. November, pp. 17-26, 2018.

[3] T. A. Setiawan, A. Ilyas, and A. P. Wibowo, "Pencegahan dan Edukasi Masyarakat Dalam Penanganan Endemik Penyakit Berbasis Web Untuk Peningkatan Kesehatan Masyarakat di Kota Pekalongan,” J. Litbang Kota Pekalongan, vol. 15, pp. 35-42, 2018.

[4] M. J. Andrés-costa, J. Pascual-aguilar, V. Andreu, and Y. Picó, "Assessing Drugs Of Abuse Distribution in Turia River Based On Geographic Information System and Liquid Chromatography Mass Spectrometry," Sci. Total Environ., vol. 609, pp. 360-369, 2017.

[5] K. Ardiansyah, "Sistem Informasi Geografis (SIG) Pemetaan Jaringan Pipa dan Titik Properti Pelanggan di PT Aetra Air Tangerang," J. Ilm. FIFO, vol. IX, no. 1, pp. 81-89, 2017.

[6] T. Twinam, "Danger Zone : Land Use and The Geography of Neighborhood Crime," $J$. Urban Econ., vol. 100, pp. 104-119, 2017.

[7] L. Safanelli et al., "Terrain Analysis in Google Earth Engine: A Method Adapted for High-Performance Global-Scale Analysis," Int. J. Geo-Information, pp. 1-13, 2020.

[8] A. S. Jamaluddin, A. Rauf, A. Rasam, N. Khalid, and M. A. Halim, "Exploring Open Source GIS for Drug Mapping and Analysis in Malaysia," 2018 IEEE 8th Int. Conf. Syst. Eng. Technol., no. October, pp. 91-96, 2018.

[9] N. Widjiyati, E. Utami, E. Pramono, S. Informasi, and G. Sig, "Sistem Informasi Geografis Penyebaran Pasien Narkoba,” J. Tek. Inform., vol. XIV, pp. 88-95, 2019.

[10] Sugiyono, Metode Penelitian Kuantitatif Kualitatif dan R\&D, 2nd ed. Alfabeta, 2019.

[11] B. S. Bell, R. E. Hoskins, L. W. Pickle, and D. Wartenberg, "Current practices in spatial analysis of cancer data: Mapping health statistics to inform policymakers and the public," Int. J. Health Geogr., vol. 5, pp. 1-14, 2006. 
[12] Sutejo, "Pemodelan UML Sistem Informasi Geografis Pasar Tradisional Kota Pekanbaru," J. Teknol. Inf. Komun. Digit. Zo., vol. 7, no. 2, pp. 89-99, 2016.

[13] M. M. Nowak and K. Dzi, "Mobile GIS Applications For Environmental Field Surveys : A State Of The A rt," Glob. Ecol. Conserv., vol. 23, pp. 1-11, 2020.

[14] D. Li and M. Lu, "Automation in Construction Integrating Geometric Models, Site Images and GIS Based on Google Earth and Keyhole Markup Language," Autom. Constr., vol. 89, no. April 2017, pp. 317-331, 2018.

[15] J. Koskinen, U. Leinonen, A. Vollrath, A. Ortmann, E. Lindquist, and R. Annunzio, "Participatory Mpping of Forest Plantations With Open Foris and Google Earth Engine," ISPRS J. Photogramm. Remote Sens., vol. 148, no. October 2018, pp. 63-74, 2019.

[16] H. Tamiminia, B. Salehi, M. Mahdianpari, L. Quackenbush, S. Adeli, and B. Brisco, "Google Earth Engine For Geo Big Data Applications : A Meta-Analysis and Systematic Review," ISPRS J. Photogramm. Remote Sens., vol. 164, no. March, pp. 152-170, 2020.

[17] J. Kolejka, "Landscape Mapping Using GIS and Google Earth Data," Geogr. Nat. Resour., vol. 3, pp. 147-155, 2018.

[18] S. Pranawa, S. Yuliani, and R. Humsona, "Meningkatkan Pengetahuan Remaja Tentang Bahaya Penyalahgunaan Narkoba Dengan Peer Education Strategy," J. Pendidikan, Sosiol. dan Antropol., vol. 2, no. 2, pp. 183-194, 2018.

[19] T. Chandra et al., "Integration of health education intervention to improve the compliance to mass drug administration for soil-transmitted helminths infection in Bangladesh: An implementation research," Parasite Epidemiol. Control, vol. 11, pp. 1$9,2020$.

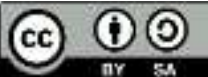

Digital Zone: Jurnal Teknologi Informasi dan Komunikasi is licensed under a Creative Commons Attribution International (CC BY-SA 4.0) 